\title{
Antioxidant and Regulatory Role of Mitochondrial Uncoupling Protein UCP2 in Pancreatic $\beta$-cells
}

\author{
P. JEŽEK ${ }^{1}$, T. OLEJÁR ${ }^{1}$, K. SMOLKOVÁ ${ }^{1}$, J. JEŽEK ${ }^{\mathbf{1}}$, A. DLASKOVÁ ${ }^{\mathbf{1}}$, \\ L. PLECITÁ-HLAVATÁ ${ }^{1}$, J. ZELENKA ${ }^{1}$, T. ŠPAČEK $^{1}$, H. ENGSTOVÁ ${ }^{1}$, \\ D. PAJUELO REGUERA ${ }^{1}$, M. JABŮREK ${ }^{1}$
}

${ }^{1}$ Department of Membrane Transport Biophysics, Institute of Physiology Academy of Sciences of the Czech Republic, Prague, Czech Republic

Received June 28, 2013

Accepted August 2, 2013

\section{Summary}

Research on brown adipose tissue and its hallmark protein, mitochondrial uncoupling protein UCP1, has been conducted for half a century and has been traditionally studied in the Institute of Physiology (AS CR, Prague), likewise UCP2 residing in multiple tissues for the last two decades. Our group has significantly contributed to the elucidation of UCP uncoupling mechanism, fully dependent on free fatty acids (FFAs) within the inner mitochondrial membrane. Now we review UCP2 physiological roles emphasizing its roles in pancreatic $\beta$-cells, such as antioxidant role, possible tuning of redox homeostasis (consequently UCP2 participation in redox regulations), and fine regulation of glucose-stimulated insulin secretion (GSIS). For example, NADPH has been firmly established as being a modulator of GSIS and since UCP2 may influence redox homeostasis, it likely affects NADPH levels. We also point out the role of phospholipase iPLA2 isoform $\gamma$ in providing FFAs for the UCP2 antioxidant function. Such initiation of mild uncoupling hypothetically precedes lipotoxicity in pancreatic $\beta$-cells until it reaches the pathological threshold, after which the antioxidant role of UCP2 can be no more cell-protective, for example due to oxidative stress-accumulated mutations in mtDNA. These mechanisms, together with impaired autocrine insulin function belong to important causes of Type 2 diabetes etiology.

\section{Key words}

Mitochondrial uncoupling protein UCP2 - Pancreatic $\beta$-cells • Homeostasis of reactive oxygen species - Redox regulations • Mitochondria • Glucose-stimulated insulin secretion

\section{Corresponding author}

P. Ježek, Department of Membrane Transport Biophysics, No. 75, Institute of Physiology, Academy of Sciences of the Czech Republic, Vídeňská 1083, CZ 14220 Prague, Czech Republic. Fax: +420-296442488. E-mail: jezek@biomed.cas.cz

\section{Introduction}

Research on brown adipose tissue, brown adipose tissue mitochondria and later, after its discovery, research on the mitochondrial uncoupling protein UCP1, has been conducted for half a century and has been traditionally studied in the Institute of Physiology, Academy of Sciences of the Czech Republic, Prague, Czech Republic (Novák et al. 1965, Drahota et al. 1968, 1970, Hahn 1970, Houštěk and Drahota 1975, 1977, Houštěk et al. 1978, Svoboda et al. 1981, Kopecký et al. 1984, 1987, Ježek et al. 1988, 1989, 1990a,b, Ježek and Drahota 1989). Our group has significantly contributed to the elucidation of UCP uncoupling mechanism, fully dependent on free fatty acids (FFAs) within the inner mitochondrial membrane (see Chapter 2.1). In 1997, UCP2 with widespread distribution in tissues has been discovered (Gimeno et al. 1997, Fleury et al. 1997) and since then the idea started that physiological uncoupling should serve to important function. That is why we review UCP2 physiological roles emphasizing its roles in pancreatic $\beta$-cells, such as antioxidant role, possible tuning of redox homeostasis (consequently UCP2 participation in redox regulations), and fine regulation of

PHYSIOLOGICAL RESEARCH • ISSN 0862-8408 (print) • ISSN 1802-9973 (online)

(c) 2014 Institute of Physiology v.v.i., Academy of Sciences of the Czech Republic, Prague, Czech Republic

Fax +420 241062 164, e-mail: physres@biomed.cas.cz, www.biomed.cas.cz/physiolres 
glucose-stimulated insulin secretion (GSIS).

\section{Delicate redox homeostasis in pancreatic $\beta$-cells}

Mitochondrial reactive oxygen species (ROS) sources and redox buffers

Similarly to other cell types (Ježek and Hlavatá 2005), mitochondrial respiratory chain is the main source of superoxide $\left(\mathrm{O}_{2}{ }^{\circ-}\right.$, and its conjugated acidhydroperoxyl radical, $\mathrm{HO}_{2}{ }^{\bullet}$, pKa 4.9) in mitochondrion of pancreatic $\beta$-cells. Complex $\mathrm{I}$, an $\mathrm{H}^{+}$-pumping NADH:quinone oxidoreductase, is considered to produce maximum superoxide only when both electron transport and $\mathrm{H}^{+}$pumping are retarded (Dlasková et al. 2008a,b). $\mathrm{H}^{+}$pumping may be attenuated by high electrochemical gradient of protons established at inner mitochondrial membrane (IMM), termed proton-motive force, $\Delta \mathrm{p}$, when expressed in $\mathrm{mV}$ units; or inhibited by oxidative stressrelated mutations of ND5 subunit (or other mitochondrion-coded subunits). Intermediate $\mathrm{O}_{2}{ }^{\bullet-}$ formation results from fully reduced flavin as reported for isolated Complex I (Pryde and Hirst 2011). Binding of rotenone and similar inhibitors in proximity to the Q-site (a ubiquinone binding site) highly retards electron transport throughout the peripheral arm of Complex I. This was originally ascribed to the formation of longerlived semiquinone species having a higher probability of reacting with oxygen which thus would form $\mathrm{O}_{2}{ }^{\bullet-}$ (Brand et al. 2004). Nevertheless, a detailed mechanism of $\mathrm{O}_{2}{ }^{-}$formation within Complex $\mathrm{I}$ and its relation to $\mathrm{H}^{+}$-pumping have yet to be established. It is well recognized, however, that nearly all Complex I-produced $\mathrm{O}_{2}{ }^{--}$is released to the matrix compartment (Brand et al. 2004). Complex III, a ubiquinol-cytochrome c reductase, contributes to $\mathrm{O}_{2}{ }^{\bullet-}$ generation by autooxidation of the ubisemiquinone anion radical ( $\mathrm{UQ}^{\bullet}$ ) within so-called Q cycle (Muller et al. 2003, Brand et al. 2004, Ježek and Hlavatá 2005), while it releases $\mathrm{O}_{2}{ }^{--}$about equally to both sides of the inner mitochondrial membrane (IMM, Muller et al. 2003, 2004).

A fast electron flux via the whole respiratory chain at a high substrate pressure (NADH/NAD ${ }^{+}$ratio) produces more $\mathrm{O}_{2}{ }^{--}$than under conditions, when slower flux occurs at the same relative retardation (same oxidation/reduction states). Hence, in intact respiratory chain, mostly effectors that retard cytochrome $\mathrm{c}$ turnover between Complex III and IV (cytochrome c oxidase), slow down $\mathrm{Q}$ cycle or CoQ migration between Complex I and III, accelerate superoxide production (Ježek and Plecitá-Hlavatá 2009).

As we discussed earlier, mitochondria represent an important cellular ROS source, which may be under certain circumstances dominant (Ježek and Hlavatá 2005). Non-mitochondrial ROS sources and their significance for pancreatic $\beta$-cells have been reviewed recently by us (Ježek et al. 2012) as together with cell antioxidant and redox buffer systems determine the overall ROS homeostasis and hence also the development of oxidative stress (Ježek and Hlavatá 2005). In pancreatic $\beta$-cells a strong non-mitochondrial ROS source is represented by NADPH oxidases, namely isoforms NOX1, 2, and 4 (Newsholme et al. 2009). Together with the weak antioxidant defense system and low capacity of redox buffers in pancreatic $\beta$-cells, it creates a delicate ROS homeostasis, which might be disturbed by a rather weak insult (Lenzen et al. 1996, Tiedge et al. 1997).

Likewise in all cell types, redox buffers and antioxidant enzymes in pancreatic $\beta$-cells are contained in mitochondrial matrix, cytosolic and other cell compartments (organelles, Ježek et al. 2012). Redox buffers and antioxidant enzymes detoxify the produced ROS and may exert specific roles in redox signaling. Catalase (absent in mitochondria except of the heart), glutathione peroxidase (GPX), and superoxide dismutase (SOD1 or CuZnSOD) represent the three of the most important intracellular antioxidant enzymes, a primary defense system. Whereas SOD2 or MnSOD and GPX4 are specific for mitochondrial matrix, SOD1 also localizes to the mitochondrial intermembrane space. However, the expression and activity of antioxidant enzymes is low in rodent $\beta$-cells compared to other organs (Lenzen 2008). This property increases their susceptibility to oxidative insult. Besides vitamin $\mathrm{E}$ ( $\alpha$-tocopherol), ascorbate and uric acid, among small antioxidant molecules, glutathione provides an important mechanism protecting $\beta$-cells against oxidative damage (Krause et al. 2011). Glutathione, present in $\mathrm{mM}$ concentrations, is kept in the reduced state (GSH) by glutathione reductase. GSH transfers its reducing equivalents to ascorbate, GPX, and glutaredoxins.

The main protein antioxidant defense is composed of disulfide reductases, namely thioredoxin (TRX), glutaredoxin (GRX), peroxiredoxins (PRX) and glutamate-cysteine ligase. Thioredoxin represents a disulfide reductase for protein sulfhydryl groups, maintaining proteins in the reduced state (Bachnoff et al. 2011). Thioredoxin reductase uses electrons from 
NADPH and regenerates oxidized TRX. Similarly, glutaredoxin reductase-2 (Reinbothe et al. 2009) reduces $\mathrm{H}_{2} \mathrm{O}_{2}$ or hydroperoxy-fatty acyl lipid chains to water or hydroxy lipid chains, respectively, at the expense of conversion of GSH to oxidized glutathione GSSG, which is regenerated by glutathione reductase. Peroxiredoxins are a family of thiol peroxide reductases which uses TRX or other thiol-containing proteins to clear $\mathrm{H}_{2} \mathrm{O}_{2}$ or lipid peroxides (Zhao and Wang 2012). Peroxiredoxin reaction product is sulfenic acid. At the TRX shortage, peroxiredoxin is inactivated to $\mathrm{PRX}-\mathrm{SO}_{2}$ (Yang et al. 2002), which can be reversed by sulfiredoxins, at the expense of ATP, yielding PRX-SOH.

\section{Mild uncoupling attenuates mitochondrial ROS} generation at intact mtDNA

Oxidative phosphorylation (OXPHOS) at mitochondrial ATP synthase (Complex V) is driven by the protonmotive force, $\Delta \mathrm{p}$, formed by the respiratory pumping chain $\mathrm{H}^{+}$at Complex I, III, and IV. The IMM domain of ATP synthase, $\mathrm{F}_{\mathrm{O}}$ ATPase, consumes an adequate $\Delta \mathrm{p}$ portion in a state, historically termed state- 3 . In vivo cellular respiration is governed by the metabolic state and/or availability of substrates, a finely tuned spectrum of various states- 3 can be established, depending on the substrate load (e.g. increasing glucose). A state-4, is then given by zero ATP synthesis, when zero $\mathrm{H}^{+}$backflux via the $\mathrm{F}_{\mathrm{O}}$ ATPase proceeds while respiration and $\mathrm{H}^{+}$pumping are given by so-called $\mathrm{H}^{+}$leak, mediated by mitochondrial carrier proteins as their side-function or given by the native $\mathrm{H}^{+}$permeability of IMM. Since mitochondrial $\Delta \mathrm{p}$ is predominantly in the form of $\Delta \Psi_{\mathrm{m}}$, IMM electrical potential, $\Delta \Psi_{\mathrm{m}}$ is maximum at state- 4 at the maximum substrate load. Besides other proteins, such as the ADP/ATP carrier, dissipation of the protonmotive force within IMM, a protonophoric short-circuit, also known as uncoupling, can be physiologically provided by mitochondrial uncoupling proteins (UCPs) (see below). When carrier-mediated protonophore activity plus IMM $\mathrm{H}^{+}$leak does not overwhelm the $\mathrm{F}_{\mathrm{O}}$ ATPase protonophoric activity, then ATP synthesis, hence OXPHOS, still takes place. Such a mild uncoupling (mild in contrast to a complete uncoupling by agents termed uncouplers) is, however, beneficial in terms of lowering mitochondrial $\mathrm{O}_{2}{ }^{\bullet-}$ formation. $\mathrm{O}_{2}{ }^{\bullet-}$ formation at both Complex I (Dlasková et al. 2008a,b) and Complex III (Korshunov et al. 1997) was reported to be diminished by mild uncoupling. Due to a relative predominance of mitochondrial ROS source within the cell, one can predict that even accumulated oxidative stress might be attenuated by mild uncoupling. Note, however, that oxidative stress originating from irreversible changes, such as stress due to mutated subunits encoded by mitochondrial DNA (mtDNA) cannot be improved by mild uncoupling (Dlasková et al. 2008a). An example is given by certain mutations of ND5 subunit of Complex I (ensuring $\mathrm{H}^{+}$pumping in intact wild-type form) that inhibit $\mathrm{H}^{+}$pumping and lead to increased $\mathrm{O}_{2}{ }^{\bullet-}$ formation. Such a block is not withdrawn by uncoupling. In conclusion, retardation of $\mathrm{H}^{+}$pumping which accelerates Complex $\mathrm{I}_{2}{ }^{\bullet-}$ formation rather initiates further turn of a vicious spiral of self-accelerated oxidative stress (Dlasková et al. 2008a).

Oxidative phosphorylation (OXPHOS) as determinant of glucose-stimulated insulin secretion (GSIS) but also mitochondrial ROS generation

Pancreatic $\beta$-cells sense glucose via elevated OXPHOS (Ashcroft and Rorsman 2012). Their respiration and OXPHOS rates, leading to a certain ATP/ADP ratio, are strictly given by the availability of glucose, whereas in most other cell types it is the other way around - cell demand dictates respiration/ metabolism rates and the ATP/ADP ratio. It is because pyruvate cannot be easily diverted towards lactate dehydrogenase for lactate formation and therefore $\beta$-cells cannot metabolize glucose by aerobic glycolysis. Canonical mechanism has been established predicting that the increased ATP/ADP ratio in $\beta$-cell cytosol initiates more frequent closure of the ATP-sensitive $\mathrm{K}^{+}$-channels (Bennet et al. 2010, Szollosi et al. 2010, Soty et al. 2011), thus depolarizing plasma membrane and activating voltage-gated L-type $\mathrm{Ca}^{2+}$-channels (Rorsman et al. 2012). The resulting $\mathrm{Ca}^{2+}$ entry elevates submembrane $\mathrm{Ca}^{2+}$ concentration and stimulates $\mathrm{Ca}^{2+}$ dependent exocytosis of insulin-containing secretory granules (Ashcroft and Rorsman 2012).

For cells not completely depleted of glucose, we hypothesized (Ježek et al. 2012) that the release of superoxide to the mitochondrial matrix upon the GSIS onset is diminished with regard to the release rates at lower glucose concentrations. GSIS should simultaneously result in the decrease of mitochondrial oxidative stress. The incremental increase of electron flow through the respiratory chain is not high at $\sim 3 \mathrm{mM}$ glucose, and its rise due to a further glucose intake is relatively lower when compared with the effect of $\mathrm{H}^{+}$ backflow via the $\mathrm{F}_{\mathrm{O}}$ part of ATP synthase that elevates 
respiration (classic respiratory control for isolated mitochondria). Thus the effect of elevated OXPHOS intensity prevails and ROS production is attenuated. This should be valid also for decrease of mitochondrial ROS formation with decreasing ADP, hence increasing ATP (Fridlyand and Philipson 2004) and has been experimentally observed (Koshkin et al. 2003). In turn, at extensive glucose depletion, the effect of substrate load (a directly proportional increase in superoxide formation, e.g. on Complex I, with increasing NADH or respiration) should overcome the suppressing role of $\mathrm{H}^{+}$returning via $\mathrm{F}_{\mathrm{O}} \mathrm{ATPase}$ at higher intensity of OXPHOS. Hence, experimentally, results of increasing mitochondrial ROS upon GSIS might be observed using dihydrodichlorofluorescein diacetate fluorescent probe (CM-H2DCFDA, further abbreviated DCF) (Bindokas et al. 2003, Sakai et al. 2003, Leloup et al. 2009) as well as increasing reducing equivalents (Patterson et al. 2000).

Since $\mathrm{H}_{2} \mathrm{O}_{2}$ of mitochondrial origin may readily access cytosol, one may report on mitochondrial ROS contribution, when measuring cytosolic ROS sensitive to mitochondrial inhibitors. As explained above, a various extent of glucose depletion may provide distinct outcome in ROS assays, which are further dependent on the employed probe. Thus using dihydroethidium fluorescent monitoring in primary rat $\beta$-cells, Martens et al. (2005) have found that unlike in non- $\beta$-cells, oxidative stress diminishes with increasing glucose upon GSIS. ROS decrease monitored by DCF upon GSIS has also been indicated in isolated Langerhans islets (Lacraz et al. 2009). Other laboratories have reported increases in ROS upon GSIS (Bindokas et al. 2003, Sakai et al. 2003, Leloup et al. 2009). Note, that insulin secretion in INS1 cells was also induced by exogenous $\mathrm{H}_{2} \mathrm{O}_{2}$ and diethyl maleate ( $\mathrm{Pi}$ et al. 2007), or by mono-oleoyl-glycerol (Saadeh et al. 2012), which increase intracellular $\mathrm{H}_{2} \mathrm{O}_{2}$.

\section{Autocrine insulin and mitochondrial ROS generation}

Autocrine insulin has acute $(4 \mathrm{~h})$ effects on GSIS in healthy humans (Bouche et al. 2010). Studies of Poderoso group have pointed out an emerging role of mitochondrial NO synthase (mtNOS) activated upon insulin signaling via the Akt-2/protein-kinase-B-mediated phosphorylation in skeletal muscle (Finocchietto et al. 2008). Released nitric oxide, a freely permeable radical, $\mathrm{NO}^{\bullet}$, having a half-life of 1 to $10 \mathrm{~s}$, causes a mild oxidative and nitrosative stress but also transiently diminishes respiration. In skeletal muscle and liver $\mathrm{NO}^{\bullet}$ facilitates conversion of glucose to glycogen.
Experimentally, it has been demonstrated by a sustained insulin dosage that the insulin-Akt-2-mtNOS pathway mediates $\mathrm{NO}^{\bullet}$ burst in skeletal muscle (Finocchietto et al. 2008). Also, nitric oxide donors increase glucose uptake in primary human skeletal muscle cells (Henstridge et al. 2009). Signaling via phosphatidyl-inositol-3-kinase (PI3K) (and hence downstream Akt-2 signaling) was responsible for insulin receptor activation by nonpeptidyl mimetic L-783,281 which inhibited GSIS as well as basal insulin secretion in human islets of Langerhans (Persaud et al. 2002). Also a direct observation in isolated mitochondria that insulin signaling regulates mitochondrial function in $\beta$-cells has been reported (Liu et al. 2009).

Since pancreatic $\beta$-cells contain a functional insulin receptor (Kulkarni et al. 1999, Brennand et al. 2007, Okada et al. 2007), an acute autocrine insulin signaling may lead to similar acute effects as in skeletal muscle and liver, besides chronic positive effects on stimulation of $\beta$-cell proliferation (Brennand et al. 2007), hence being beneficial for regulation of adult $\beta$-cell mass. Transgenic mice lacking insulin receptor in pancreatic $\beta$-cells ( $\beta$ IRKO mice) exhibited increased apoptosis, decreased proliferation, and reduced $\beta$-cell mass (Kulkarni et al. 1999). The insulin receptor has also been found essential for islet compensatory growth response to insulin resistance (Okada et al. 2007). There are two arms of autocrine insulin signaling via insulin receptor, the Raf-1 kinase arm and the Akt kinase arm. Insulin stimulates primary $\beta$-cell proliferation via Raf-1 kinase and suppresses apoptosis. The Akt arm increases $\beta$-cell mass and improves glucose tolerance. A signalosome complex of glucokinase, pro-apoptotic protein, Bcl-2associated death promoter, $\mathrm{BAD}_{\mathrm{S}}$, and protein kinase $\mathrm{A}$ has been reduced in $\beta$ IRKO mice, thus linking a lack of autocrine insulin with development of Type 2 diabetes (Liu et al. 2009).

If mtNOS is indeed activated upon insulin signaling in $\beta$-cells, the predicted outcome may substantiate different roles than in skeletal muscle cells and hepatocytes, just due to the impossibility to switch to a partial aerobic glycolysis and provide a spectrum of anaplerotic pathways. The released $\mathrm{NO}^{\bullet}$ may transiently inhibit Complex I and cytochrome c oxidase. $\mathrm{NO}^{\bullet}$ may also react with superoxide, thus forming peroxynitrite which can further act against otherwise diminishing mitochondrial superoxide production. 


\section{Mitochondrial uncoupling proteins}

\section{Decades of uncoupling protein research}

Mitochondrial uncoupling proteins (UCPs) belong to the SLC25 anion carrier family, having 46 members, among which five UCP isoforms have been identified (Palmieri 2013). The historically first, UCP1, has been discovered and ascribed as specific to brown adipose tissue (BAT) where it provides the final key unit of catabolic cascade of nonshivering thermogenesis (Cannon et al. 2006). Nevertheless, our present knowledge indicates that thermogenesis is given not only by UCP1 expression but also by specific composition of BAT mitochondria, namely the lowered ATP synthase content. All other UCPs due to the lack of such a specific mitochondrial set-up and due to much lower amounts existing in tissues do not provide excessive heat release and rather tune OXPHOS efficiency in a way to regulate complex molecular physiology of mitochondria within the cell. It is difficult to assess the physiological impact of UCP2-mediated uncoupling of OXPHOS because the minute amounts of UCP2 expressed in tissues give rise to a small effect, leading only to a small decrease in IMM potential $\left(\Delta \Psi_{\mathrm{m}}\right)$ on the order of single-millivolts that are difficult to measure (Ježek et al. 2004).

$\mathrm{UCP} 2$, as a second discovered isoform by Tartaglia (Gimeno et al. 1997) and independently reported by Ricquier's and Warden's group (Fleury et al. 1997), was first characterized via its transcript widely distributed in all mammalian tissues, whereas UCP3 transcript was found specifically in BAT, skeletal muscle and heart (Boss et al. 1997, Vidal-Puig et al. 1997). Apparently more brain-specific isoforms UCP4 (Mao et al. 1999) and UCP5 (originally called BMCP) have been also identified (Sanchis et al. 1998, Yu et al. 2000, KimHan et al. 2001, Lengacher et al. 2004).

The two aspects now revealed had delayed understanding of UCP functions and physiological roles. At first, translational downregulation (Pecqueur et al. 2001, Hurtaud et al. 2006) diminishing UCP expression, likewise up-regulation has been described (Hurtaud et al. 2007), so the protein amount is not proportional to the transcript. Moreover, UCP2 lifetime has been found to be extremely short, so regulations of its expression possess a nearly direct switch-on/of regulation of UCP2 presence. Simultaneously, as predominant integral membrane proteins with dimeric six membrane-spanning $\alpha$ helices, UCPs are difficult to be selectively recognized by antibodies and cross-reactions occurs with all 46 SLC25 family members (Ježek et al. 1999, Pecqueur et al. 2001). The second aspect was lying in the disputes on the own uncoupling mechanism as described below, and led to theoretical misconceptions such as consideration of fatty acid (FA) export by UCP3 (Seifert et al. 2008).

From the bioinformatics point of view, uncoupling proteins UCP1, UCP2, UCP3, UCP4, and UCP5 form a distinct subfamily within the gene family of mitochondrial anion carriers (Ježek and Urbánková 2000, Hanák and Ježek 2001, Ježek and Ježek 2003, Klingenspor et al. 2008). In terms of homology, the closest carrier to UCPs is the oxoglutarate carrier, which, however, lacks the unique uncoupling protein signature sequences (Ježek and Urbánková 2000, Hanák and Ježek 2001, Ježek and Ježek 2003).

The advent of gene ablation and silencing led to influential pioneer findings showing surprising UCP roles. Thus already the report of Nègre-Salvayre et al. (1997) could be interpreted as suppression of ROS production due to the UCP2 function. They observed an increased $\mathrm{H}_{2} \mathrm{O}_{2}$ production due to $\Delta \Psi_{\mathrm{m}}$ increase induced by GDP addition, likely mediated by UCP 2 in macrophage (liver Kupffer cell) mitochondria or in thymus and spleen mitochondria. UCP2(-/-) mice were more resistant to Toxoplasma gondii infection due to higher macrophage attack (Arsenijevic et al. 2000), excellently demonstrating how mitochondrial ROS homeostasis affects not only cellular but also extracellular ROS homeostasis (detailed description in Ježek and Hlavatá 2005). Simply, higher mitochondrial ROS production due to the lack of UCP2 antioxidant function had spread towards cytosol, overwhelmed the redox buffers and antioxidant mechanisms therein, hence more ROS were left for microbe killing. Actually, the additional ROS were probably superimposed to the classic macrophage activated NADPH oxidase ROS formation. Similarly, UCP3(-/-) mice exhibited higher levels of ROS in muscle (Vidal-Puig et al. 2000). Another surprise came from the suggestion that UCP2 regulates glucose-stimulated insulin secretion (GSIS, Zhang et al. 2001, Krauss et al. 2005, Parker et al. 2009, see below). But this is just one of numerous examples how fine tuning of OXPHOS may be related to crucial physiological phenomena. Another such example (Trenker et al. 2007, Wu et al. 2009) is the observation that UCP2 may be fundamental for the regulation of $\mathrm{Ca}^{2+}$ levels in mitochondria. Indeed, uncoupling is strictly affecting $\mathrm{Ca}^{2+}$ uptake and efflux via IMM, diminishing $\Delta \Psi_{\mathrm{m}}$-dependent $\mathrm{Ca}^{2+}$ uniport uptake, likewise 
$\Delta$ pH-dependent $\mathrm{Ca}^{2+}$ efflux via $\mathrm{Ca}^{2+} / \mathrm{Na}^{+}$and $\mathrm{Ca}^{2+} / \mathrm{H}^{+}$ carriers. Even though such a physiological role for UCP2 has been challenged by other groups (Brookes et al. 2008), we may speculate that the observation of UCP2-dependent $\mathrm{Ca}^{2+}$ uptake may reflect the ability of $\mathrm{Ca}^{2+}$-complexed fatty acid anions to interact with UCPs in combination of $\Delta \mathrm{p}$ effects on $\mathrm{Ca}^{2+}$ fluxes.

A number of studies also pointed to the attention to UCP2 in cancer cells (Baffy 2010). UCP2 overexpression has been reported for a variety of cancer cells and linked to enhanced tumor formation in the soft agar or xenograft model (Ayyasamy et al. 2011). Several lines of evidence also suggested a role of UCP2 in cancer chemoresistence. For instance, UCP2 overexpression in colon cancer cells resulted in diminished apoptosis (caspase-3 activation) in response to etoposide, doxorubicine, CPT and UV radiation in vitro as well as in xenograft studies with UCP2 overexpressing cells, by suppressing the phosphorylation of p53 within the transactivating domain via inhibition the ROS production (Derdak et al. 2008). UCP2 upregulation should help cells to escape from apoptosis mediated by the p53 signaling. UCP2-dependent chemoresistance is believed to be based on quenching of drug-induced ROS burst by promoting proton leak. Indeed, inhibiting of UCP2 by diamine-induced glutathionylation (Pfefferle et al. 2013) or siRNA (Dalla Pozza et el. 2012) causes augmented drug sensitivity using various chemotherapeutics.

Recently, UCP1 has also been detected in thymocytes (Carroll et al. 2005, Adams et al. 2008a,b), where its thermogenic role is probably replaced by a regulatory role in apoptosis due to its ability to attenuate mitochondrial ROS production (Dlasková et al. 2006, 2010).

Uncoupling mechanism of mitochondrial uncoupling proteins - fatty acid wobbling

In spite of the fact that the crystallographic structure of UCP2 has been described (Berardi et al. 2011), likewise the structure of the prototypical SLC25 family member, the ADP/ATP carrier (Pebay-Peyroula et al. 2003), molecular mechanism of uncoupling was not deduced from structure but from numerous functional studies of reconstituted UCPs. We have been for long time involved in this research (e.g. Ježek et al. 1997a,b, Urbánková et al. 2003, Žáćková et al. 2003, Jabůrek et al. 2004) and such pioneer studies turned out to be closest to the recently established model (Fedorenko et al. 2012) (Fig. 1).
1) RCOO= uniport

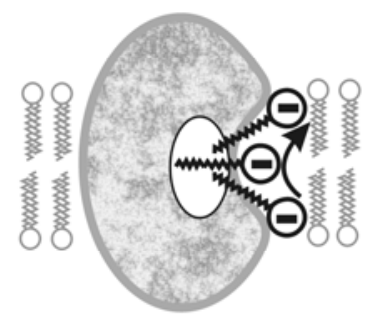

3) $\mathrm{RCOOH}$ uniport

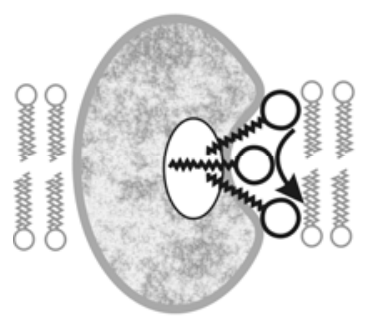

2) Protonation
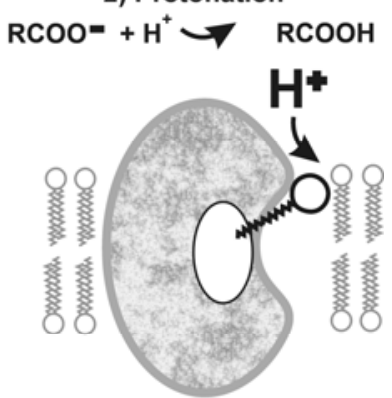

4) Deprotonation

$\mathrm{RCOOH} \underset{\mathrm{RCOO}}{-}+\mathrm{H}^{+}$

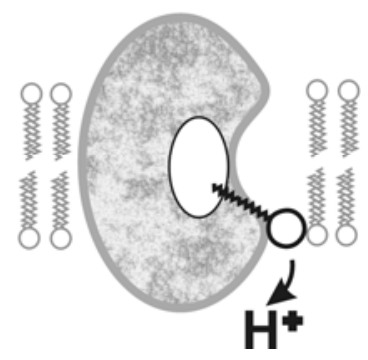

Fig. 1. Fatty acid wobbling mechanism of uncoupling protein mediated uncoupling. Schemas depict the four steps of fatty acid wobbling mechanism suggested by Fedorenko et al. (2012).

During the decades of UCP research, mutually incompatible models for uncoupling mechanism have been developed (Skulachev 1991, Garlid et al. 1996, Ježek et al. 1998, Klingenberg and Echtay 2001, Krauss et al. 2005, Cannon et al. 2006), which had to include the indisputable facts that the function of all UCPs is initiated by free fatty acids (FFAs). Nevertheless, models that considered UCP as a protonophore had viewed FFA function as a simple facilitation of $\mathrm{H}^{+}$flux into the entry of a " $\mathrm{H}^{+}$channel" (Klingenberg and Winkler 1985, Winkler and Klingenberg 1992, 1994, Gonzalez-Barroso et al. 1998, Klingenberg and Huang 1999), though no amino acid residues that would constitute such a channel were ever found. The second model, originally expressed by Skulachev (1991), as fatty acid cycling hypothesis, was in fact developed for all members of SCL25 family and predicted that when an anion carrier via its anionic pathway may (even if accidentally) conduct anionic fatty acid (FA), then, spontaneous return of protonated FA via the lipid bilayer ensures the $\mathrm{H}^{+}$flux. The FA cycling model has been supported by our numerous studies.

However, recently, using a patch clamp technique to investigate the transport mechanism of UCP1 in native environment of brown adipose tissue mitochondria, a study by Fedorenko et al. (2012) has 
confirmed that all prerequisites published by Ježek and Garlid (1990) two decades ago were valid (see also Strieleman et al. 1985a,b, Ježek et al. 1990b, 1994, 1996, 1997a,b, 1998, 2004, Murdza-Inglis et al. 1991, Garlid et al. 1996, 1998, 2000, 2001, Ježek and Borecký 1998, Jabůrek et al. 1999, 2003, Jabůrek and Garlid 2003, Žáčková et al. 2003). These patch clamp results together with fatty acid binding studies supported a modified FA cycling model, where FA is not detaching from the protein but is all the time bound to the UCP binding site, from which it alternatively exposes anionic group to the cis and trans side of the membrane (Fedorenko et al. 2012). Thus all premises of the original FA cycling model (Skulachev 1991) were fulfilled, but one, i.e. that FA does not diffuse out of the protein binding site. Such a hindered diffusion has been indicated by our previous EPR studies of UCP1 using 5-DOXYL-stearic acid (Ježek and Freisleben 1994, Ježek et al. 1995).

Fedorenko et al. (2012) suggested that FA anions are moved within UCPs from cis to trans side of the membrane so that the tail still interacts with the protein, nevertheless anionic $\mathrm{COO}^{-}$group is exposed at both sides (Fig. 1). After movement to the trans side, protonation occurs and protonated FAs are internalized into the cis side by the analogous but counter-directional way and thus carry a proton across the membrane. Such a "local FA cycling" or "wobbling" mechanism cannot proceed with so-called inactive FAs (Ježek et al. 1997a,b) or long chain or short chain alkylsulfonates (Garlid et al. 1996). The resulting uncoupling would continue until all free FAs are metabolized or removed from IMM by binding to cytosolic FA binding proteins or mitochondrial components that have greater affinities for FAs (Ježek et al. 1998).

Moreover, we have shown that UCP2 transports more readily polyunsaturated FAs (PUFAs; Žáčková et al. 2003) and hydroperoxy FAs (Jabůrek et al. 2004) using recombinant purified UCP2 reconstituted into liposomes or black lipid membranes (Beck et al. 2007).

\section{On and off switching of UCP2 function}

The extent of UCP's activation is not only governed by FFAs but also owing to the state of inhibition by purine nucleotides (Beck et al. 2007). The absolute protein amounts, that may be instantly regulated, serve as a basic parameter for rough estimation of UCP functional relevance in a given tissue under given physiological conditions. It has been reported that lipid peroxidation products, e.g. 4-hydroxy-2-nonenal, may also act as enhancers of UCP-mediated uncoupling by chemical modification of UCPs (Echtay et al. 2002a,b, 2003). However, recent study of Fedorenko et al. (2012) showed that 4-hydroxy-2-nonenal has no effect on the FFA-dependent $\mathrm{H}^{+}$transport mediated by native UCP1.

Moreover, Fedorenko et al. (2012) provided further characteristics of FFA-mediated initiation of UCP uncoupling in revealing that it is the nascent FFA, cleaved off phospholipids within the membrane, which preferentially interacts with UCP. This claim, if found accurate, may explain numerous published unsuccessful attempts to elucidate FA role when simple FFA additions were made (e.g. Cunningham et al. 1986, Couplan et al. 2002, Galletti et al. 2009). Already in 2004, we have considered that mitochondria-localized phospholipases A2 (PLA2) can suit such a role (Jabůrek et al. 2004). We have originally considered that due to reported preferences of certain PLA2s, probably hydroperoxyFFAs are cleaved off and initiate UCP2-mediated uncoupling (Skulachev and Goglia 2003). However, $\mathrm{Ca}^{2+}$-independent phospholipase A2 isoform $\gamma$ (PNPLA8 subfamily of phospholipases A2) has been identified which cleaves not only fatty acid residues from the $s n-2$ positions which are mostly unsaturated, but also from sn-1 positions, hence unsaturated FFAs are cleaved (Murakami et al. 2011). Recently, we have demonstrated in heart (Ježek J. et al. 2010), lung and spleen (Jabůrek et al. 2013) and even in pancreatic $\beta$-cell mitochondria (Ježek, Dlasková, Jabůrek, et al., unpublished) that mitochondrial iPLA2 $\gamma$ (mt-iPLA2 $\gamma$ ) is activated by ROS, most probably directly by $\mathrm{H}_{2} \mathrm{O}_{2}$ (Zelenka, Jabůrek, et al., unpublished) and may provide FFAs for either ADP/ATP carrier plus residual UCPs in the heart mitochondria or for abundant UCP2 in lung, spleen and $\beta$-cell mitochondria (Fig. 2). The consequent synergy of $\mathrm{H}_{2} \mathrm{O}_{2}$ activated mt-iPLA2 $\gamma$ and UCP2 thus forms a feedback downregulation of mitochondrial ROS production and may protect against oxidative stress in vivo.

We may conclude that besides the acute switchon of UCP2 expression and maybe concomitant partial suppression of its degradation, redox activation of mt-iPLA2 $\gamma$ is required for UCP2 function. This mechanism may explain even the series of studies when the increase in mitochondrial superoxide production was interpreted as direct UCP upregulation by superoxide or via 4-hydroxy-2-nonenal (Echtay et al. 2002a,b, 2003).

In addition to the regulation of UCP2 by the redox state via mt-iPLA2 $\gamma$, a direct redox-sensitive modification of UCPs is not ruled out. A reversible 
glutationylation was suggested to act as a control switch for UCP2- and UCP3-dependent uncoupling (Mailloux et al. 2011). Thus glutathionylation may enhance GSIS and, conversely, increase in mitochondrial ROS was found to deglutathionylate and activate UCP2 and consequently impede GSIS (Mailloux et al. 2012). Glutathionylation status of UCP2 thus may contribute to the regulation of GSIS.

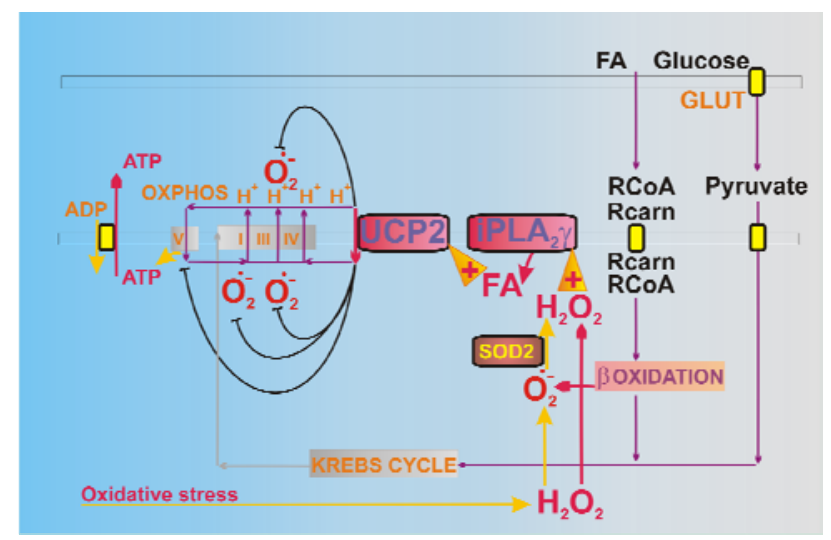

Fig. 2. Synergy of UCP2 and iPLA2 $\gamma$ providing an antioxidant role. Schema depicts the role of UCP2 and mt-iPLA $2 \gamma$ in pancreatic $\beta$-cells. For explanations see text.

Evidences that UCP2 attenuates mitochondrial ROS generation

Previously, an antioxidant role for UCP2 has been scarcely demonstrated in vivo (Nègre-Salvayre et al. 1997, Arsenijevic et al. 2000). For example, Duval et al. (2002) have shown that UCP2-mediated uncoupling in endothelial cells is even able to decrease extracellular ROS in co-incubated low-density lipoproteins (LDL). Mice with deleted LDL receptor exhibited extensive dietinduced atherosclerotic plaques when they received bone marrow transplanted from UCP2(-/-) mice, and appearance of these plaques was prevented when they received bone marrow transplants from $\mathrm{UCP} 2(+/+)$ mice (Blanc et al. 2003).

Recently, we have demonstrated for the first time UCP2-mediated suppression of mitochondrial superoxide production in vitro (Jabůrek et al. 2013). We have shown that mt-iPLA2 $\gamma$ and UCP2 act in concert to protect against oxidative stress in isolated mitochondria and extended this finding to protein carbonylation in lung and spleen tissue (unpublished). The revealed feedback downregulation of oxidative stress is provided by the synergic action of $\mathrm{H}_{2} \mathrm{O}_{2}$ - (or TBHP-)activated mt-iPLA2 $\gamma$ and $\mathrm{UCP} 2$, because elimination of either protein prevents synergy. Thus, synergy of $\mathrm{H}_{2} \mathrm{O}_{2}$-activated mt-iPLA2 $\gamma$ and UCP2 protects against oxidative stress in vivo (Fig. 2). In pancreatic $\beta$-cells, such FFA feedback downregulation of ROS production (Ježek, Dlasková, Jabůrek, et al., unpublished) is related to the early stages of lipotoxicity which is protected until a certain threshold during the onset of progressive pathology is reached.

\section{The UCP2 role in pancreatic $\beta$-cells}

\section{Antioxidant role}

Let us further focus on UCP2 antioxidant role in pancreatic $\beta$-cells. Likewise in other cell types, UCP2 may exert an important antioxidant role in $\beta$-cells while preventing excessive superoxide formation within the respiratory chain (Robson-Doucette et al. 2011). In pancreatic $\beta$-cells it has been observed that UCP2mediated mild uncoupling decreases the yield of ATP from glucose (Chan et al. 2001, Zhang et al. 2001). Further studies suggested superoxide activation of UCP2-mediated uncoupling on the basis of observation of elevated $\Delta \Psi_{\mathrm{m}}$ in islets treated with a superoxide dismutase (SOD) mimetic manganese [III] tetrakis (4-benzoic acid) porphyrin (MnTBAP) or overexpressing MnSOD, absent in islets from UCP2 KO mice (Krauss et al. 2011). Upon presumed inhibition of UCP2-mediated uncoupling by genipin, $\Delta \Psi_{\mathrm{m}}$ increased in wild type islets but not in UCP2 KO islets (Zhang et al. 2006). UCP2 overexpression in INS-1 cells attenuated IL1 $\beta$-induced ROS formation (Produit-Zengaffinen et al. 2007). With UCP2 silencing, a mild uncoupling in mitochondria isolated from INS-1E cells was linked to UCP2, while accounting for up to $30 \%$ of $\mathrm{H}^{+}$leak (Affourtit and Brand 2008). UCP2-mediated uncoupling was detectable also in intact INS-1E cells as compared to those silenced for UCP2 (Affourtit et al. 2001). In turn, Galletti et al. (2009) could not demonstrate any effect of UCP2 overexpression on mitochondrial coupling in INS-1 cells, neither after oleate addition. The chronic absence of UCP2 in UCP2 KO mice of three highly congenic strain backgrounds caused oxidative stress reflected by decreased GSH/GSSG ratio in blood or examined tissues while their islets had elevated levels of antioxidant enzymes and increased nitrotyrosine content ( $\mathrm{Pi}$ et al. 2009). Pancreatic $\beta$-cells from UCP2 KO mice had chronically higher ROS when compared to wt mice (Lee et al. 2009). Mice with selective knock-out of UCP2 in pancreatic $\beta$-cells (UCP2BKO mice) exhibited somewhat increased glucose-induced $\Delta \Psi_{\mathrm{m}}$ (Robson-Doucette et al. 
2011). UCP2BKO mice had also elevated intracellular ROS levels as determined by DCF (Robson-Doucette et al. 2011). These results comply with the antioxidant function of UCP2-mediated mild uncoupling. UCP2 may also modulate redox signaling, if could be effectively switched on and off.

Tuning of redox balance and participation in redox signaling

Cytosolic ROS sources in pancreatic $\beta$-cells were reviewed by us recently as well as concomitant redox information signaling (Ježek et al. 2012). Hypothetically, redox signaling during apoptosis initiation may reflect the important role of UCPs in immune cells (Carroll et al. 2005, Adams et al. 2008a,b). As already described above, mild uncoupling may tune mitochondrial ROS production and thus participate in redox regulations. In turn a reversible glutathionylation or glutaredoxin-2 upregulation (Mailloux et al. 2013) may act as a control of UCP-participation in redox signaling.

Uncoupling, however, also promotes mitochondrial fission, i.e. disintegration of mitochondrial network into small objects containing usually one or several nucleoids of mtDNA (Tauber et al. 2013) that can be theoretically more readily degraded within them, under certain circumstances by mitophagy, a mitochondria-specific authophagy (Gomes and Scorrano 2013). Mitophagy, however, when exerted in optimum frequency might be beneficial to cell, namely due to degradation of oxidatively-modified cell constituents, hence mild uncoupling promoting "mild" mitophagy should be physiological.

Autophagy is a „self-eating“ process allowing control on degradation of either insoluble protein aggregates or damaged organelles (mitochondria, endoplasmatic reticulum, etc.) in lysozomes (Murrow et al. 2013) and is involved in lipid control (Christian et al. 2013). Dysregulated autophagy and mitophagy is a generally accepted mechanism that is involved in diseases related to aging, including Type 2 diabetes mellitus (T2DM, Horan et al. 2012, Hubbard et al. 2012). Synergically with glucose FFAs block autophagic turnover in pancreatic $\beta$-cells (Las et al. 2011). Impairment of insulin secretion was also associated with deficient autophagy in animal model, when marked decrease in autophagy-cascade-related proteins like microtubule-associated protein 1 light chain 3 (LC3/Atg8), LC3 II/I ratio and autophagy-related protein 7 (Atg7) or lysosomal-associated membrane protein 2
(LAMP2) together with increase of sequestosome-1 (SQSTM1/p62) and polyubiquitinated protein aggregates were recorded in aged rats (Liu et al. 2013). Mice with $\beta$-cell-specific Atg7 deletion showed reduced $\beta$-cell mass and pancreatic insulin content, however, they have not developed diabetes. Upon breeding these mice with obese $(o b / o b)$ mice, animals became diabetic (Quan et al. 2012). Reduced autophagy may lead to a significant susceptibility to additional long-acting injury of $\beta$-cells in elderly-like hyperlipidemia and even moderate hyperglycemia due to the insulin resistance, both related to diet-induced obesity. In turn, UCP2-mediated mild uncoupling can be beneficial to promote a slight fission of mitochondrial network and contribute to the physiologically required intensity of mitophagy. In pancreatic adenocarcinoma cells, UCP2 inhibition or silencing lead to ROS increase and expression of autophagic marker LC3 II (Dando et al. 2013).

\section{Regulation of glucose-stimulated insulin secretion (GSIS)}

The intimately specific feature of pancreatic $\beta$-cells lies in glucose sensing through the OXPHOS (Ashcroft and Rorsman 2012). Respiration and OXPHOS rates, leading to a certain ATP/ADP ratio, are governed by the availability of glucose, whereas in most other cell types, cell demand dictates respiration/metabolism rates and the ATP/ADP ratio. It is because of a specific enzyme/regulation pattern of $\beta$-cells (Ježek et al. 2012). At first, unlike in numerous other cell types, pyruvate cannot be diverted towards lactate dehydrogenase for lactate formation in $\beta$-cells. Consequently, glucose cannot be metabolized by aerobic glycolysis, which provides so-called Warburg phenotype in cancer cells and under physiological cell responses to hypoxia and other adaptations (Ježek et al. 2010, Smolková et al. 2011). Thus nearly $100 \%$ of glucose is metabolized by OXPHOS in $\beta$-cells (likewise in hepatocytes and numerous differentiated OXPHOS cells). The pattern of pyruvate dehydrogenase kinase (PDK) genes is surely responsible for this (Ježek et al. 2012). Thus, $\beta$-cell PDK1 and PDK3 are "constitutively blocked", and PDK2 is "inefficient" so that it does not phosphorylate PDH E1 $\alpha$ subunit of pyruvate dehydrogenase (PDH), hence does not inhibit its activity. At low basal glucose, PDH is $90 \%$ active, whereas at maximum glucose PDH is inhibited only by $22 \%$. Also hexokinase IV (glucokinase) in $\beta$-cells is not inhibited by glucose-6phosphate, as in e.g. skeletal muscle cells. The lack of such a feedback inhibition of glycolysis directly connects 
glycolysis to pyruvate. Finally, the human glucose transporter GLUT1 or rodent GLUT2 are not dependent on insulin, so glucose in $\beta$-cell cytosol is proportional to bloodstream glucose. This is a perfect setting for a sensor. Consequently, glucose metabolism in $\beta$-cells is finely adjusted to the blood glucose levels (Merglen et al. 2004). At starvation with $\sim 3 \mathrm{mM}$ glucose levels, $\beta$-cell respiration is relatively low, as well as the intensity of ATP synthesis, corresponding to the established state-3 ${ }_{[\mathrm{Glc}=3 \mathrm{mM}]}$ (Liang et al. 1997, Porterfield et al. 2000, Špaček et al. 2008). The $\Delta \Psi_{\mathrm{m}}$ is still lower than would be at state-4 with $3 \mathrm{mM}$ glucose. Increasing glucose intake into $\beta$-cells, may increase up to OXPHOS-saturating $\sim 12$ to $15 \mathrm{mM}$ glucose, when maximum OXPHOS takes places with the established state- $3_{\max }$, maximum respiration and maximum $\Delta \Psi_{\mathrm{m}}$ (Špaček et al. 2008). The resulting increased $\mathrm{ATP} / \mathrm{ADP}$ ratio in the cell cytosol initiates closure of plasma membrane ATP-sensitive $\mathrm{K}^{+}$ channels (Ashcroft and Rorsman 2012), leading to plasma membrane depolarization and opening of voltagesensitive $\mathrm{Ca}^{2+}$ channels. Increased cytosolic $\mathrm{Ca}^{2+}$ initiates insulin granule exocytosis. It has been hypothesized that $\beta$-cells maintain a relatively high $[\mathrm{ATP}] /[\mathrm{ADP}]$ value even in low glucose and that glucose metabolism leads to dramatically decreased free ADP with only modestly increased ATP (Fridlyand and Philipson 2004). If a high $[\mathrm{ATP}] /[\mathrm{ADP}]$ ratio exists even at low glucose levels, as a result, the total adenine nucleotide concentration is unchanged during a glucose-induced elevation. GSIS was also reported to be modulated or accelerated by other metabolic pathways related to mitochondria, such as phosphocreatine shuttle, additional $\mathrm{Ca}^{2+}$ signaling due to glutamate metabolism (Maechler et al. 2006, Casimir et al. 2009), citrate export (Joseph et al. 2006), phosphoenolpyruvate (Stark et al. 2006) and pyruvate cycling (Heart et al. 2009, Jitrapakdee et al. 2010). A common denominator in these modulations is NADPH, the role of which on insulin secretion has yet to be established. Overall, GSIS possesses also a component due to the autocrine function of insulin. The UCP2 function in GSIS regulation has been firmly established
(Chan et al. 2001, Zhang et al. 2001). Now we hypothesize, that due to UCP2 participation in redox regulations and due to redox homeostasis effects on the NADPH content, UCP2 may exert the second arm for GSIS fine tuning, the redox regulation arm.

\section{Future perspectives}

Due to its complex health and economic sequels as well as steadily increasing prevalence, Type 2 diabetes mellitus represents one of the serious burdens of the 21th century. Its pathogenesis is complex and different factors may prevail in individual cases. The typical feature of progressed $\mathrm{T} 2 \mathrm{DM}$ is insulin resistance as well as $\beta$-cell dysfunction (Ashcroft and Rorsman 2012, Ježek et al. 2012). In future research it will probably be established whether T2DM is an inevitable disease and whether one may develop a strategy to highly retard or completely exclude the pathological outcomes of progressive selfaccelerating oxidative stress and nitrosative stress and concomitant dysregulated information signaling. The emerging role of redox signaling in GSIS and processes of molecular physiology of pancreatic $\beta$-cells need to be elucidated as well. Unfortunately, neither targeted antioxidants might be able to defeat T2DM, since they simultaneously disrupt the inherent physiological redox signaling. Perhaps more focused strategies on yet unknown mechanisms will help to defeat T2DM world epidemics. Molecular research on UCP2 roles during diabetes development may significantly contribute to this goal.

\section{Conflict of Interest}

There is no conflict of interest.

\section{Acknowledgements}

This work has been supported by Grant Agency of the Czech Republic, grant No. P302/10/0346 to P. J., P305/12/1247 to M. J. and P304/10/P204 to A. D., as well as within the project The Centre of Biomedical Research (CZ.1.07/2.3.00/30.0025).

\section{References}

ADAMS AE, CARROLL AM, FALLON PG, PORTER RK: Mitochondrial uncoupling protein 1 expressio in thymocytes. Biochim Biophys Acta 1777: 772-776, 2008a.

ADAMS AE, HANRAHAN O, NOLAN DN, VOORHEIS HP, FALLON P, PORTER RK: Images of mitochondrial UCP 1 in mouse thymocytes using confocal microscopy. Biochim Biophys Acta 1777: 115-117, $2008 \mathrm{~b}$. 
AFFOURTIT C, BRAND MD: Uncoupling protein-2 contributes significantly to high mitochondrial proton leak in INS-1E insulinoma cells and attenuates glucose-stimulated insulin secretion. Biochem J 409: 84-93, 2008.

AFFOURTIT C, JASTROCH M, BRAND MD: Uncoupling protein-2 attenuates glucose-stimulated insulin secretion in INS-1E insulinoma cells by lowering mitochondrial reactive oxygen species. Free Radic Biol Med 50: 609-616, 2001.

ARSENIJEVIC D, ONUMA H, PECQUEUR C, RAIMBAULT S, MANNING BS, COUPLAN E, ALVES-GUERRA MC, GOUBERN M, SURWIT R, BOUILLAUD F, RICHARD D, COLLINS S, RICQUIER D: Disruption of the uncoupling protein 2 gene in mice reveals a role in immunity and reactive oxygen species production. Nat Genet 26: 435-439, 2000.

ASHCROFT FM, RORSMAN P: Diabetes mellitus and the $\beta$ cell: the last ten years. Cell 148: 1160-1171, 2012.

AYYASAMY V, OWENS KM, DESOUKI MM, LIANG P, BAKIN A, THANGARAJ K, BUCHSBAUM DJ, LOBUGLIO AF, SINGH KK: Cellular model of Warburg effect identifies tumor promoting function of UCP2 in breast cancer and its suppression by genipin. PLoS One 6: e24792, 2011.

BACHNOFF N, TRUS M, ATLAS D: Alleviation of oxidative stress by potent and selective thioredoxin-mimetic peptides. Free Radic Biol Med 50: 1355-1367, 2011.

BAFFY G: Uncoupling protein-2 and cancer. Mitochondrion 10: 243-252, 2010.

BECK V, JABU゚REK M, DEMINA T, RUPPRECHT A, PORTER RK, JEŽEK P, POHL EE: High efficiency of polyunsaturated fatty acids in the activation of human uncoupling protein 1 and 2 reconstituted in planar lipid bilayers. FASEB J 21: 1137-1144, 2007.

BENNET K, JAMES C, HUSSAIN K: Pancreatic beta-cell KATP channels: Hypoglycaemia and hyperglycaemia. Rev Endocrin Metab Disord 11: 157-163, 2010.

BERARDI MJ, SHIH WM, HARRISON SC, CHOU JJ: Mitochondrial uncoupling protein 2 structure determined by NMR molecular fragment searching. Nature 476: 109-113, 2011.

BINDOKAS VP, KUZNETSOV A, SREENAN S, POLONSKY KS, ROE MW, PHILIPSON LH: Visualizing superoxide production in normal and diabetic rat islets of Langerhans. J Biol Chem 278: 9796-9801, 2003.

BLANC J, ALVES-GUERRA MC, ESPOSITO B, ROUSSET S, GOURDY P, RICQUIER D, TEDGUI A, MIROUX B, MALLAT Z: Protective role of uncoupling protein 2 in atherosclerosis. Circulation 107: 388-390, 2003.

BOSS O, SAMEC S, PAOLONI-GIACOBINO A, ROSSIER C, DULLOO A, SEYDOUX J, MUZZIN P, GIACOBINO JP: Uncoupling protein-3: a new member of the mitochondrial carrier family with tissue-specific expression. FEBS Lett 408: 39-42, 1997.

BOUCHE C, LOPEZ X, FLEISCHMAN A, CYPESS AM, O'SHEA S, STEFANOVSKI D, BERGMAN RN, ROGATSKY E, STEIN DT, KAHN CR, KULKARNI RN, GOLDFINE AB: Insulin enhances glucosestimulated insulin secretion in healthy humans. Proc Natl Acad Sci USA 107: 4770-4775, 2010.

BRAND MD, AFFOURTIT C, ESTEVES TC, GREEN K, LAMBERT AJ, MIWA S, PAKAY JL, PARKER N: Mitochondrial superoxide: production, biological effects, and activation of uncoupling proteins. Free Radic Biol Med 37: 755-767, 2004.

BRENNAND K, HUANGFU D, MELTON D: All beta cells contribute equally to islet growth and maintenance. PLoS Biol 5: e163, 2007.

BROOKES PS, PARKER N, BUCKINGHAM JA, VIDAL-PUIG A, HALESTRAP AP, GUNTER TE, NICHOLLS DG, BERNARDI P, LEMASTERS JJ, BRAND MD: UCPs-unlikely calcium porters. Nat Cell Biol 10: 12351237, 2008.

CANNON B, SHABALINA IG, KRAMAROVA TV, PETROVIC N, NEDERGAARD J: Uncoupling proteins: a role in protection against reactive oxygen species - or not? Biochim Biophys Acta 1757: 449-458, 2006.

CARROLL AM, HAINES LR, PEARSON TW, FALLON PG, WALSH CM, BRENNAN CM: Identification of a functioning mitochondrial uncoupling protein 1 in thymus. J Biol Chem 280: 15534-15543, 2005.

CASIMIR M, LASORSA FM, RUBI B, CAILLE D, PALMIERI F, MEDA P, MAECHLER P: Mitochondrial glutamate carrier $\mathrm{GC1}$ as a newly identified player in the control of glucose-stimulated insulin secretion. $J$ Biol Chem 284: 25004-25014, 2009. 
CHAN CB, DE LEO D, JOSEPH JW, MCQUAID TS, HA XF, XU F, TSUSHIMA RG, PENNEFATHER PS, SALAPATEK AM, WHEELER MB: Increased uncoupling protein-2 levels in beta-cells are associated with impaired glucose-stimulated insulin secretion: mechanism of action. Diabetes 50: 1302-1310, 2001.

CHRISTIAN P, SACCO J, ADELI K: Autophagy: emerging roles in lipid homeostasis and metabolic control. Biochim Biophys Acta 1831: 819-824, 2013.

COUPLAN E, GONZALES-BARROSO MDM, ALVES-GUERRA MC, RICQUIER D, GOUBERN M, BOUILLAUD F: No evidence for a basal, retinoic, or superoxide-induced uncoupling activity of the uncoupling protein 2 present in spleen or lung mitochondria. J Biol Chem 277: 26268-26275, 2002.

CUNNINGHAM SA, WIESINGER H, NICHOLLS DG: Quantification of fatty acid activation of the uncoupling protein in brown adipocytes and mitochondria from the guinea-pig. Eur J Biochem 157: 415-420, 1986.

DALLA POZZA E, FIORINI C, DANDO I, MENEGAZZI M, SGARBOSSA A, COSTANZO C, PALMIERI M, DONADELLI M: Role of mitochondrial uncoupling protein 2 in cancer cell resistance to gemcitabine. Biochim Biophys Acta 1823: 1856-1863, 2012.

DANDO I, FIORINI C, POZZA ED, PADRONI C, COSTANZO C, PALMIERI M, DONADELLI M: UCP2 inhibition triggers ROS-dependent nuclear translocation of GAPDH and autophagic cell death in pancreatic adenocarcinoma cells. Biochim Biophys Acta 1833: 672-679, 2013.

DERDAK Z, MARK NM, BELDI G, ROBSON SC, WANDS JR, BAFFY GR: The mitochondrial uncoupling protein-2 promotes chemoresistance in cancer cells. Cancer Res 68: 2813-2819, 2008.

DLASKOVÁ A, ŠPAČEK T, ŠKOBISOVÁ E, ŠANTOROVÁ J, JEŽEK P: Certain aspects of uncoupling due to mitochondrial uncoupling proteins in vitro and in vivo. Biochim Biophys Acta 1757: 467-473, 2006.

DLASKOVÁ A, HLAVATÁ L, JEŽEK P: Oxidative stress caused by blocking of mitochondrial Complex I $\mathrm{H}^{+}$pumping as a link in aging/disease vicious cycle. Int J Biochem Cell Biol 40: 1792-1805, 2008a.

DLASKOVÁ A, HLAVATÁ L, JEŽEK J, JEŽEK P: Mitochondrial Complex I superoxide production is attenuated by uncoupling. Int J Biochem Cell Biol 40: 2098-2109, $2008 \mathrm{~b}$.

DLASKOVÁ A, CLARKE KJ, PORTER RK: The role of UCP 1 in production of reactive oxygen species by mitochondria isolated from brown adipose tissue. Biochim Biophys Acta 1797: 1470-1476, 2010.

DRAHOTA Z, HONOVÁ E, HAHN P: The effect of ATP and carnitine on the endogenous respiration of mitochondria from brown adipose tissue. Experientia 24: 431-432, 1968.

DRAHOTA Z, GAZZOTTI P, HAHN P: Respiration of brown adipose tissue from young rats. Physiol Bohemoslov 19: 363-367, 1970.

DUVAL C, NÈGRE-SALVAYRE A, DOGLIO A, SALVAYRE R, PÉNICAUD L, CASTEILLA L: Increased reactive oxygen species production with antisense oligonucleotides directed agains uncoupling protein 2 in murine endothelial cells. Biochem Cell Biol 80: 757-764, 2002.

ECHTAY KS, ROUSSEL D, ST-PIERRE J, JEKABSON MB, CADENAS S, STUART JA, HARPER JA, ROEBUCK SJ, MORRISON A, PICKERING S, CLAPHAM JC, BRAND MD: Superoxide activates mitochondrial uncoupling proteins. Nature 415: 96-99, 2002a.

ECHTAY KS, MURPHY MP, SMITH RAJ, TALBOT DA, BRAND MD: Superoxide activates mitochondrial uncoupling protein 2 from the matrix side. Studies using targeted antioxidants. J Biol Chem 277: 47129-47135, 2002 b.

ECHTAY KS, ESTEVES TC, PAKAY JL, JEKABSON MB, LAMBERT AJ, PORTERO-OTÍN M, PAMPLONA R, VIDAL-PUIG AJ, WANG S, ROEBUCK SJ, BRAND MD: A signaling role for 4-hydroxy-2-nonenal in regulation of mitochondrial uncoupling. EMBO J 22: 4103-4110, 2003.

FEDORENKO A, LISHKO PV, KIRICHOK Y: Mechanism of fatty-acid-dependent UCP1 uncoupling in brown fat mitochondria. Cell 151: 400-413, 2012.

FINOCCHIETTO P, BARREYRO F, HOLOD S, PERALTA J, FRANCO MC, MÉNDEZ C, CONVERSO DP, ESTÉVEZ A, CARRERAS MC, PODEROSO JJ: Control of muscle mitochondria by insulin entails activation of Akt2-mtNOS pathway: implications for the metabolic syndrome. PLoS One 3: 1749, 2008.

FLEURY C, NEVEROVA M, COLLINS S, RAIMBAULT S, CHAMPIGNY O, LEVI-MEYRUEIS C, BOUILLAUD F, SELDIN MF, SURWIT RS, RICQUIER D, WARDEN CH: Uncoupling protein-2: a novel gene linked to obesity and hyperinsulinemia. Nat Genet 15: 269-272, 1997. 
FRIDLYAND LE, PHILIPSON LH: Does the glucose-dependent insulin secretion mechanism itself cause oxidative stress in pancreatic beta-cells? Diabetes 53: 1942-1948, 2004.

GALETTI S, SARRE A, PERRETEN H, PRODUIT-ZENGAFFINEN N, MUZZIN P, ASSIMACOPOULOSJEANNET F: Fatty acids do not activate UCP2 in pancreatic beta cells: comparison with UCP1. Pflugers Arch 457: 931-940, 2009.

GARLID KD, OROSZ DE, MODRIANSKÝ M, VASSANELLI S, JEŽEK P: On the mechanism of fatty acid-induced proton transport by mitochondrial uncoupling protein. J Biol Chem 271: 2615-2620, 1996.

GARLID KD, JABŮREK M, JEŽEK P: The mechanism of proton transport mediated by mitochondrial uncoupling proteins. FEBS Lett 438: 10-14, 1998.

GARLID KD, JABŮREK M, JEŽEK P, VAŘECHA M: How do uncoupling proteins uncouple? Biochim Biophys Acta 1459: 383-389, 2000.

GARLID KD, JABU゚REK M, JEŽEK P: Mechanism of uncoupling protein action. Biochem Soc Trans 276: 803-806, 2001.

GIMENO RE, DEMBSKI M, WENG X, SHYJAN AW, GIMENO CJ, IRIS F, ELLIS SJ, DENG N, WOOLF EA, TARTAGLIA LA: Cloning and characterization of an uncoupling protein homolog. A potential molecular mediator of human thermogenesis. Diabetes 46: 900-906, 1997.

GOMES LC, SCORRANO L: Mitochondrial morphology in mitophagy and macroautophagy. Biochim Biophys Acta 1833: 205-212, 2013.

GONZALEZ-BARROSO MM, FLEURY C, BOUILLAUD F, NICHOLLS DG, RIAL E: The uncoupling protein UCP1 does not increase the proton conductance of the inner mitochondrial membrane by functioning as a fatty acid anion transporter. J Biol Chem 273: 15528-15532, 1998.

HAHN P: Fatty acid synthesis in brown and white adipose tissue and liver of the rat during development. Physiol Bohemoslov 19: 369-373, 1970.

HANÁK P, JEŽEK P: Mitochondrial uncoupling proteins and phylogenesis - UCP4 as the ancestral uncoupling protein. FEBS Lett 495: 137-141, 2001.

HEART E, CLINE GW, COLLIS LP, PONGRATZ RL, GRAY JP, SMITH PJ: Role for malic enzyme, pyruvate carboxylation, and mitochondrial malate import in glucose-stimulated insulin secretion. Am J Physiol Endocrinol Metab 296: E1354-E1362, 2009.

HENSTRIDGE DC, DREW BG, FORMOSA MF, NATOLI AK, CAMERON-SMITH D, DUFFY SJ, KINGWELL BA: The effect of the nitric oxide donor sodium nitroprusside on glucose uptake in human primary skeletal muscle cells. Nitric Oxide 21: 126-131, 2009.

HORAN MP, PICHAUD N, BALLARD JW: Review: quantifying mitochondrial dysfunction in complex diseases of aging. J Gerontol A Biol Sci Med Sci 67: 1022-1035, 2012.

HOUSTĔK J, DRAHOTA Z: Activity of the inner and outer membrane oxidative enzymes in brown adipose tissue mitochondria. Physiol Bohemoslov 24: 297-304, 1975.

HOUSTĚK J, DRAHOTA Z: Purification and properties of mitochondrial adenosine triphosphatase of hamster brown adipose tissue. Biochim Biophys Acta 484: 127-139, 1977.

HOUSTĔK J, KOPECKÝ J, DRAHOTA Z: Specific properties of brown adipose tissue mitochondrial membrane. Comp Biochem Physiol B 60: 209-214, 1978.

HUBBARD VM, VALDOR R, MACIAN F, CUERVO AM: Selective autophagy in the maintenance of cellular homeostasis in aging organisms. Biogerontology 13: 21-35, 2012.

HURTAUD C, GELLY C, BOUILLAUD F, LÉVI-MEYRUEIS C: Translation control of UCP2 synthesis by the upstream open reading frame. Cell Mol Life Sci 63: 1780-1789, 2006.

HURTAUD C, GELLY C, CHEN Z, LÉVI-MEYRUEIS C, BOUILLAUD F: Glutamine stimulates translation of uncoupling protein 2 mRNA. Cell Mol Life Sci 64: 1853-1860, 2007.

JABŮREK M, GARLID KD: Reconstitution of recombinant uncoupling proteins: UCP1, -2 , and -3 have similar affinities for ATP and are unaffected by coenzyme Q10. J Biol Chem 278: 25825-25831, 2003.

JABŮREK M, VAŘECHA M, GIMENO RE, DEMBSKI M, JEŽEK P, ZHANG M, BURN P, TARTAGLIA LA, GARLID KD: Transport function and regulation of mitochondrial uncoupling proteins 2 and 3. J Biol Chem 274: 26003-26007, 1999. 
JABU゚REK M, VAŘECHA M, JEŽEK P, GARLID KD: Alkylsulfonates as probes of uncoupling protein transport mechanism. Ion pair transport demonstrates that direct $\mathrm{H}^{+}$translocation by $\mathrm{UCP} 1$ is not necessary for uncoupling. J Biol Chem 276: 31897-31905, 2001.

JABŮREK M, MIYAMOTO S, DI MASCIO P, GARLID K D, JEŽEK P: Hydroperoxy fatty acid cycling mediated by mitochondrial uncoupling protein UCP2. J Biol Chem 279: 53097-53102, 2004.

JABŮREK M, JEŽEK J, ZELENKA J, JEŽEK P: Antioxidant activity by a synergy of redox-sensitive mitochondrial phospholipase A2 and uncoupling protein-2 in lung and spleen. Int J Biochem Cell Biol 45: 816-825, 2013.

JEŽEK J, JABŮREK M, ZELENKA J, JEŽEK P: Mitochondrial phospholipase A2 activated by reactive oxygen species in heart mitochondria induces mild uncoupling. Physiol Res 59: 737-747, 2010.

JEŽEK P, DRAHOTA Z: Sulfhydryl groups of the uncoupling protein of brown adipose tissue mitochondria. Distinction between sulfhydryl groups of the $\mathrm{H}+$ channel and the nucleotide binding site. Eur J Biochem 183: 89-95, 1989.

JEŽEK P, GARLID KD: New substrates and competitive inhibitors of the $\mathrm{Cl}^{-}$translocating pathway of the uncoupling protein of brown adipose tissue mitochondria. J Biol Chem 265: 19303-19311, 1990.

JEŽEK P, FREISLEBEN H-J: Fatty acid binding site of the mitochondrial uncoupling protein. Demonstration of its existence by EPR spectroscopy of 5-DOXYL-stearic acid. FEBS Lett 343: 22-26, 1994.

JEŽEK P, BORECKÝ J: The mitochondrial uncoupling protein may participate in futile cycling of pyruvate and other monocarboxylates. Am J Physiol 275: C496-C504, 1998.

JEŽEK P, URBÁNKOVÁ E: Specific sequence motifs of mitochondrial uncoupling proteins. IUBMB Life 49: 63-70, 2000.

JEŽEK P, JEŽEK J: Sequence anatomy of mitochondrial anion carriers. FEBS Lett 534: 15-25, 2003.

JEŽEK P, HLAVATÁ L: Mitochondria in homeostasis of reactive oxygen species in cell tissues and organism. Int $J$ Biochem Cell Biol 37: 2478-2503, 2005.

JEŽEK P, PLECITÁ-HLAVATÁ L: Mitochondrial reticulum network dynamics in relation to oxidative stress, redox regulation, and hypoxia. Int J Biochem Cell Biol 41: 1790-1804, 2009.

JEŽEK P, HOUŠTEK J, DRAHOTA Z: Alkaline $\mathrm{pH}$, membrane potential and magnesium cations are negative modulators of purine nucleotide inhibition of $\mathrm{H}+$ and $\mathrm{Cl}-$ transport through the uncoupling protein of brown adipose tissue mitochondria. J Bioenerg Biomembr 20: 603-622, 1988.

JEŽEK P, KRASINSKAYA IP, SMIRNOVA I, DRAHOTA Z: Carnitine cycle in brown adipose tissue mitochondria as a tool for studying the regulatory role of fatty acids in the uncoupling protein function. FEBS Lett 243: 37-40, 1989.

JEŽEK P, DRAHOTA Z, RING K: The activating effect of fatty acid on the mitochondrial uncoupling protein reconstituted in liposomes. J Lipid Mediators 2: 85-94, 1990a.

JEŽEK P, OROSZ DE, GARLID KD: Reconstitution of the uncoupling protein of brown adipose tissue mitochondria: Demonstration of GDP-sensitive halide anion uniport. J Biol Chem 265: 19296-19302, 1990b.

JEŽEK P, OROSZ DE, MODRIANSKÝ M, GARLID KD: Transport of anions and protons by the mitochondrial uncoupling protein and its regulation by nucleotides and fatty acids: A new look at old hypotheses. $J$ Biol Chem 269: 26184-26190, 1994.

JEŽEK P, BAUER M, TROMMER WE: EPR spectroscopy of 5-DOXYL stearic acid bound to the mitochondrial uncoupling protein reveals its competitive displacement by alkylsulfonates in the channel and allosteric displacement by ATP. FEBS Lett 361: 303-307, 1995.

JEŽEK P, HANUŠ J, SEMRAD C, GARLID KD: Photoactivated azido fatty acid irreversibly inhibits anion and proton transport through the mitochondrial uncoupling protein. J Biol Chem 271: 6199-6205, 1996.

JEŽEK P, MODRIANSKÝ M, GARLID KD: Inactive fatty acids are unable to flip-flop across the lipid bilayer. FEBS Lett 408: 161-165, 1997a.

JEŽEK P, MODRIANSKÝ M, GARLID KD: A structure activity study of fatty acid interaction with mitochondrial uncoupling protein. FEBS Lett 408: 166-170, 1997b.

JEŽEK P, ENGSTOVÁ H, ŽÁČKOVÁ M, VERCESI AE, COSTA ADT, ARRUDA P, GARLID KD: Fatty acid cycling mechanism and mitochondrial uncoupling proteins. Biochim Biophys Acta 1365: 319-327, 1998. 
JEŽEK P, ŽÁČKOVÁ M, ŘEHÁKOVÁ Z, RŮŽIČKA M, BORECKÝ J, ŠKOBISOVÁ E, BRUCKNEROVÁ J, GARLID KD, GIMENO RE, TARTAGLIA LA: Existence of uncoupling protein-2 antigen in isolated mitochondria from various tissues. FEBS Lett 455: 79-82, 1999.

JEŽEK P, ŽÁČKOVÁ M, RŮŽIČKA M, ŠKOBISOVÁ E, JABU゚REK M: Mitochondrial uncoupling proteins - facts and fantasies. Physiol Res 53: S199-S211, 2004.

JEŽEK P, PLECITÁ-HLAVATÁ L, SMOLKOVÁ K, ROSSIGNOL R: Distinctions and similarities of cell bioenergetics and role of mitochondria in hypoxia, cancer, and embryonic development. Int J Biochem Cell Biol 42: 604-622, 2010.

JEŽEK P, DLASKOVÁ A, PLECITÁ-HLAVATÁ L: Redox homeostasis in pancreatic beta-cells. Oxid Med Cell Longev 2012: 932838, 2012.

JITRAPAKDEE S, WUTTHISATHAPORNCHAI A, WALLACE JC, MACDONALD MJ: Regulation of insulin secretion: role of mitochondrial signalling. Diabetologia 53: 1019-1032, 2010.

JOSEPH JW, JENSEN MV, ILKAYEVA O, PALMIERI F, ALÁRCON C, RHODES CJ, NEWGARD CB: The mitochondrial citrate/isocitrate carrier plays a regulatory role in glucose-stimulated insulin secretion. $J$ Biol Chem 281: 35624-35632, 2006.

KIM-HAN JS, REICHERT SA, QUICK KL, DUGAN LL: BMCP1: a mitochondrial uncoupling protein in neurons which regulates mitochondrial function and oxidant production. J Neurochem 79: 658-668, 2001.

KLINGENBERG M, WINKLER E: The reconstituted isolated uncoupling protein is a membrane potential driven $\mathrm{H}^{+}$translocator. EMBO J 4: 3087-3092, 1985.

KLINGENBERG M, HUANG S-G: Structure and function of the uncoupling protein from brown adipose tissue. Biochim Biophys Acta 1415: 271-296, 1999.

KLINGENBERG M, ECHTAY KS: Uncoupling proteins: the issues from a biochemist point of view. Biochim Biophys Acta 1504: 128-143, 2001.

KLINGENSPOR M, FROMME T, HUGHES DA JR, MANZKE L, POLYMEROPOULOS E, RIEMANN T: An ancient look at UCP1. Biochim Biophys Acta 1777: 637-641, 2008.

KOPECKÝ J, GUERRIERI F, JEŽEK P, DRAHOTA Z, HOUSTĚK J: Molecular mechanism of uncoupling in brown adipose tissue mitochondria. The non-identity of proton and chloride conducting pathways. FEBS Lett 170: 186-190, 1984.

KOPECKÝ J, JEŽEK P, DRAHOTA Z, HOUSTĚK J: Control of uncoupling protein in brown-fat mitochondria by purine nucleotides. Chemical modification by diazobenzenesulfonate. Eur J Biochem 164: 687-694, 1987.

KORSHUNOV SS, SKULACHEV VP, STARKOV AA: High protonic potential actuates a mechanism of production of reactive oxygen species in mitochondria. FEBS Lett 416: 15-18, 1997.

KOSHKIN V, WANG X, SCHERER PE, CHAN CB, WHEELER MB: Mitochondrial functional state in clonal pancreatic beta-cells exposed to free fatty acids. J Biol Chem 278: 19709-19715, 2003.

KRAUSS S, ZHANG CY, SCORRANO L, DALGAARD LT, ST-PIERRE J, GREY ST, LOWELL BB: Superoxidemediated activation of uncoupling protein 2 causes pancreatic beta cell dysfunction. J Clin Invest 112: 1831$1842,2003$.

KRAUSS S, ZHANG CY, LOWELL BB: The mitochondrial uncoupling-protein homologues. Nat Rev Mol Cell Biol 6: 248-261, 2005.

KRAUSE MS, MCCLENAGHAN NH, FLATT PR, DE BITTENCOURT PI, MURPHY C, NEWSHOLME P: L-arginine is essential for pancreatic beta-cell functional integrity, metabolism and defense from inflammatory challenge. J Endocrinol 211: 87-97, 2011.

KULKARNI RN, BRÜNING JC, WINNAY JN, POSTIC C, MAGNUSON MA, KAHN CR: Tissue-specific knockout of the insulin receptor in pancreatic beta cells creates an insulin secretory defect similar to that in type 2 diabetes. Cell 96: 329-339, 1999.

LACRAZ G, FIGEAC F, MOVASSAT J, KASSIS N, COULAUD J, GALINIER A, LELOUP C, BAILBÉ D, HOMODELARCHE F, PORTHA B: Diabetic beta-cells can achieve self-protection against oxidative stress through an adaptive up-regulation of their antioxidant defenses. PLoS One 4: e6500, 2009.

LAS G, SERADA SB, WIKSTROM JD, TWIG G, SHIRIHAI OS: Fatty acids suppress autophagic turnover in $\beta$-cells. J Biol Chem 286: 42534-42544, 2011. 
LEE SC, ROBSON-DOUCETTE CA, WHEELER MB: Uncoupling protein 2 regulates reactive oxygen species formation in islets and influences susceptibility to diabetogenic action of streptozotocin. $J$ Endocrinol 203 : 33-43, 2009.

LELOUP C, TOURREL-CUZIN C, MAGNAN C, KARACA M, CASTEL J, CARNEIRO L, COLOMBANI AL, KTORZA A, CASTEILLA L, PÉNICAUD L: Mitochondrial reactive oxygen species are obligatory signals for glucose-induced insulin secretion. Diabetes 58: 673-681, 2009.

LENGACHER S, MAGISTRETTI PJ, PELLERIN LJ: Quantitative rt-PCR analysis of uncoupling protein isoforms in mouse brain cortex: methodological optimization and comparison of expression with brown adipose tissue and skeletal muscle. J Cereb Blood Flow Metab 24: 780-788, 2004.

LENZEN S: Oxidative stress: the vulnerable beta-cell. Biochem Soc Trans 36: 343-347, 2008.

LENZEN S, DRINKGERN J, TIEDGE M: Low antioxidant enzyme gene expression in pancreatic islets compared with various other mouse tissues. Free Radic Biol Med 20: 463-466, 1996.

LIANG Y, BUETTGER C, BERNER DK, MATSCHINSKY FM: Chronic effect of fatty acids on insulin release is not through the alternation of glucose metabolism in a pancreatic beta-cell line (betaHC9). Diabetologia 40: 1018$1027,1997$.

LIU S, OKADA T, ASSMANN A, SOTO J, LIEW CW, BUGGER H, SHIRIHAI OS, ABEL ED, KULKARNI RN: Insulin signaling regulates mitochondrial function in pancreatic beta-cells. PLoS One 4: e7983, 2009.

LIU Y, SHI S, GU Z, DU Y, LIU M, YAN S, GAO J, LI J, SHAO Y, ZHONG W, CHEN X, LI C: Impaired autophagic function in rat islets with aging. Age 35: 1531-1544, 2013.

MAECHLER P, CAROBBIO S, RUBI B: In beta-cells, mitochondria integrate and generate metabolic signals controlling insulin secretion. Int J Biochem Cell Biol 38: 696-709, 2006.

MAILLOUX RJ, SEIFERT EL, BOUILLAUD F, AGUER C, COLLINS S, HARPER ME: Glutathionylation acts as a control switch for uncoupling proteins UCP2 and UCP3. J Biol Chem 286: 21865-21875, 2011.

MAILLOUX RJ, FU A, ROBSON-DOUCETTE C, ALLISTER EM, WHEELER MB, SCREATON R, HARPER ME: Glutathionylation state of uncoupling protein-2 and the control of glucose-stimulated insulin secretion. $J$ Biol Chem 287: 39673-39685, 2012.

MAILLOUX RJ, XUAN JY, BEAUCHAMP B, JUI L, LOU M, HARPER ME: Glutaredoxin-2 is required to control proton leak through uncoupling protein-3. J Biol Chem 288: 8365-8379, 2013.

MAO W, YU XX, ZHONG A, LI W, BRUSH J, SHERWOOD SW: UCP4, a novel brain-specific mitochondrial protein that reduces membrane potential in mammalian cells. FEBS Lett 443: 326-330, 1999.

MARTENS GA, CAI Y, HINKE S, STANGÉ G, VAN DE CASTEELE M, PIPELEERS D: Glucose suppresses superoxide generation in metabolically responsive pancreatic beta cells. J Biol Chem 280: 20389-20396, 2005.

MERGLEN A, THEANDER S, RUBI B, CHAFFARD G, WOLLHEIM CB, MAECHLER P: Glucose sensitivity and metabolism-secretion coupling studied during two-year continuous culture in INS-1E insulinoma cells. Endocrinology 145: 667-678, 2004.

MULLER FL, ROBERTS AG, BOWMAN MK, KRAMER DM: Architecture of the Qo site of the cytochrome bc1 complex probed by superoxide production. Biochemistry 42: 6493-6499, 2003.

MULLER FL, LIU Y, VAN REMMEN H: Complex III releases superoxide to both sides of the inner mitochondrial membrane. J Biol Chem 279: 49064-49073, 2004.

MURAKAMI M, TAKETOMI Y, MIKI Y, SATO H, HIRABAYASHI T, YAMAMOTO K: Recent progress in phospholipase $A_{2}$ research: from cells to animals to humans. Prog Lipid Res 50: 152-192, 2011.

MURDZA-INGLIS DL, PATEL HV, FREEMAN KB, JEŽEK P, OROSZ DE, GARLID KD: Functional reconstitution of rat uncoupling protein following its high level expression in yeast. J Biol Chem 266: 11871-11875, 1991.

MURROW L, DEBNATH J: Autophagy as a stress-response and quality-control mechanism: implications for cell injury and human disease. Annu Rev Pathol 8: 105-137, 2013.

NÈGRE-SALVAYRE A, HIRTZ C, CARRERA G, CAZENAVE R, TROLY M, SALVAYERE R, PENICAUD L, CAISTEILA LA: A role for uncoupling protein-2 as a regulator of mitochondrial hydrogen peroxide generation. FASEB J 11: 809-815, 1997. 
NEWSHOLME P, MORGAN D, REBELATO E, OLIVEIRA-EMILIO HC, PROCOPIO J, CURI R, CARPINELLI A: Insights into the critical role of NADPH oxidase(s) in the normal and dysregulated pancreatic beta cell. Diabetologia 52: 2489-2498, 2009.

NOVÁK M, MELICHAR V, HAHN P, KOLDOVSKÝ O: Release of free fatty acids from adipose tissue obtained from newborn infants. $J$ Lipid Res 6: 91-95, 1965.

OKADA T, LIEW CW, HU J, HINAULT C, MICHAEL MD, KRÜTZFELDT J, YIN C, HOLZENBERGER M, STOFFEL M, KULKARNI RN: Insulin receptors in beta-cells are critical for islet compensatory growth response to insulin resistence. Proc Natl Acad Sci USA 104: 8977-8982, 2007.

PALMIERI F: The mitochondrial transporter family SLC25: identification, properties and physiopathology. Mol Aspects Med 34: 465-484, 2013.

PARKER N, VIDAL-PUIG AJ, AZZU V, BRAND MD: Dysregulation of glucose homeostasis in nicotinamide nucleotide transhydrogenase knockout mice is independent of uncoupling protein 2. Biochim Biophys Acta 1787: 1451-1457, 2009.

PATTERSON GH, KNOBEL SM, ARKHAMMAR P, THASTRUP O, PISTON DW: Separation of the glucosestimulated cytoplasmic and mitochondrial NAD(P)H responses in pancreatic beta cells. Proc Natl Acad Sci USA 97: 5203-5207, 2000.

PEBAY-PEYROULA E, DAHOUT-GONZALES C, KAHN M, TREZEGUET V, LAUQUIN GJ-M, BRANDOLIN G: Structure of mitochondrial ADP/ATP carrier in complex with carboxyatractyloside. Nature 426: 39-44, 2003.

PECQUEUR C, ALVES-GUERRA M-C, GELLY C, LÉVI-MEYRUEIS C, COUPLAN E, COLLINS S, RICQUIER D, BOUILLAUD F, MIROUX B: Uncoupling protein 2, in vivo distribution, induction upon oxidative stress, and evidence for translational regulation. J Biol Chem 276: 8705-8712, 2001.

PERSAUD SJ, ASARE-ANANE H, JONES PM: Insulin receptor activation inhibits insulin secretion from human islets of Langerhans. FEBS Lett 510: 225-228, 2002.

PFEFFERLE A, MAILLOUX RJ, ADJEITEY CN-K, HARPER M-E: Glutathionylation of UCP2 sensitizes drug resistant leukemia cells to chemotherapeutics. Biochim Biophys Acta 1833: 80-89, 2013.

PI J, BAI Y, ZHANG Q, WONG V, FLOERING LM, DANIEL K, REECE JM, DEENEY JT, ANDERSEN ME, CORKEY BE, COLLINS S: Reactive oxygen species as a signal in glucose-stimulated insulin secretion. Diabetes 56: 1783-1791, 2007.

PI J, BAI Y, DANIEL KW, LIU D, LYGHT O, EDELSTEIN D, BROWNLEE M, CORKEY BE, COLLINS S: Persistent oxidative stress due to absence of uncoupling protein 2 associated with impaired pancreatic beta-cell function. Endocrinology 150: 3040-3048, 2009.

PORTERFIELD DM, CORKEY RF, SANGER RH, TORNHEIM K, SMITH PJS, CORKEY BE: Oxygen consumption oscillates in single clonal pancreatic beta-cell (HIT). Diabetes 49: 1511-1516, 2000.

PRODUIT-ZENGAFFINEN N, DAVIS-LAMELOISE N, PERRETEN H, BÉCARD D, GJINOVCI A, KELLER PA, WOLLHEIM CB, HERRERA P, MUZZIN P, ASSIMACOPOULOS-JEANNET F: Increasing uncoupling protein-2 in pancreatic beta cells does not alter glucose-induced insulin secretion but decreases production of reactive oxygen species. Diabetologia 50: 84-93, 2007.

PRYDE KR, HIRST J: Superoxide is produced by the reduced flavin in mitochondrial complex I: a single, unified mechanism that applies during both forward and reverse electron transfer. J Biol Chem 286: 18056-18065, 2011.

QUAN W, LIM YM, LEE MS: Role of autophagy in diabetes and endoplasmic reticulum stress of pancreatic $\beta$-cells. Exp Mol Med 44: 81-88, 2012.

REINBOTHE TM, IVARSSON R, LI DQ, NIAZI O, JING X, ZHANG E, STENSON L, BRYBORN U, RENSTRÖM E: Glutaredoxin-1 mediates NADPH-dependent stimulation of calcium-dependent insulin secretion. Mol Endocrinol 23: 893-900, 2009.

ROBSON-DOUCETTE CA, SULTAN S, ALLISTER EM, WIKSTROM JD, KOSHKIN V, BHATTACHARJEE A, PRENTICE KJ, SEREDA SB, SHIRIHAI OS, WHEELER MB: Beta-cell uncoupling protein 2 regulates reactive oxygen species production, which influences both insulin and glucagon secretion. Diabetes 60: 2711027119, 2011. 
RORSMAN P, BRAUN M, ZHANG Q: Regulation of calcium in pancreatic $\alpha$ - and $\beta$-cells in health and disease. Cell Calcium 51: 300-308, 2012.

SAADEH M, FERRANTE TC, KANE A, SHIRIHAI O, CORKEY BE, DEENEY JT: Reactive oxygen species stimulate insulin secretion in rat pancreatic islets: studies using mono-oleoyl-glycerol. PLoS One 7: e30200, 2012.

SANCHIS D, FLEURY C, CHOMIKI N, GOUBERN M, HUANG Q, NEVEROVA M: BMCP1, a novel mitochondrial carrier with high expression in the central nervous system of humans and rodents, and respiration uncoupling activity in recombinant yeast. J Biol Chem 273: 34611-34615, 1998.

SAKAI K, MATSUMOTO K, NISHIKAWA T, SUEFUJI M, NAKAMARU K, HIRASHMIA Y, KAWASHIMA J, SHIROTANI T, ICHINOSE K, BROWNLEE M, ARAKI E: Mitochondrial reactive oxygen species reduce insulin secretion by pancreatic beta-cells. Biochem Biophys Res Commun 300: 216-222, 2003.

SEIFERT EL, BÉZAIRE V, ESTEY C, HARPER ME: Essential role for uncoupling protein-3 in mitochondrial adaptation to fasting but not in fatty acid oxidation or fatty acid anion export. $J$ Biol Chem 283: 25124-25131, 2008.

SKULACHEV VP: Fatty acid circuit as a physiological mechanism of uncoupling of oxidative phosphorylation. FEBS Lett 294: 158-162, 1991.

SKULACHEV VP, GOGLIA: A function for novel uncoupling proteins: antioxidant defense of mitochondrial matrix by translocating fatty acid peroxides from the inner to the outer membrane leaflet. FASEB $J$ 17: 1585-1591, 2003.

SMOLKOVÁ K, PLECITÁ-HLAVATÁ L, BELLANCE N, BENARD G, ROSSIGNOL R, JEŽEK P: Waves of gene regulation suppress and then restore oxidative phosphorylation in cancer cells. Int $J$ Biochem Cell Biol 43: 950-968, 2011.

SOTY M, VISA M, SORIANO S, CARMONA MDEL C, NADAL Á, NOVIALS A: Involvement of ATP-sensitive potassium (K(ATP)) channels in the loss of beta-cell function induced by human islet amyloid polypeptide. J Biol Chem 286: 40857-40866, 2011.

ŠPAČEK T, ŠANTOROVÁ J, ZACHAROVOVÁ K, BERKOVÁ Z, HLAVATÁ L, SAUDEK F, JEŽEK P: Glucose stimulated-insulin secretion of insulinoma INS1-E cells is associated with elevation of both respiration and mitochondrial membrane potential. Int J Biochem Cell Biol 40: 1522-1535, 2008.

STARK R, PASQUEL F, TURCU A, PONGRATZ RL, RODEN M, CLINE GW, SHULMAN GI, KIBBEY RG: Phosphoenolpyruvate cycling via mitochondrial phosphoenolpyruvate carboxykinase links anaplerosis and mitochondrial GTP with insulin secretion. J Biol Chem 284: 26578-26590, 2009.

STRIELEMAN PJ, SCHALINSKE KL, SHRAGO E: Fatty acid activation of the reconstituted brown adipose tissue mitochondria uncoupling protein. J Biol Chem 260: 13402-13405, 1985a.

STRIELEMAN PJ, SCHALINSKE KL, SHRAGO E: Partial purification and functional reconstitution of GDP-sensitive brown adipose tissue mitochondrial uncoupling protein using octylglucoside. Biochem Biophys Res Commun 127: 509-516, 1985 b.

SVOBODA P, HOUSTĚK J, KOPECKÝ J, DRAHOTA Z: Evaluation of the specific dicyclohexylcarbodiimide binding sites in brown adipose tissue mitochondria. Biochim Biophys Acta 634: 321-330, 1981.

SZOLLOSI A, NENQUIN M, HENQUIN JC: Pharmacological stimulation and inhibition of insulin secretion in mouse islets lacking ATP-sensitive K+ channels. Br J Pharmacol 159: 669-677, 2010.

TAUBER J, DLASKOVÁ A, ŠANTOROVÁ J, SMOLKOVÁ K, ALÁN L, ŠPAČEK T, PLECITÁ-HLAVATÁ L, JABŮREK M, JEŽEK P: Distribution of mitochondrial nucleoids upon mitochondrial network fragmentation and network reintegration in HEPG2 cells. Int J Biochem Cell Biol 45: 593-603, 2013.

TIEDGE M, LORTZ S, DRINKGERN J, LENZEN S: Relation between antioxidant enzyme gene expression and antioxidative defense status of insulin-producing cells. Diabetes 46: 1733-1742, 1997.

TRENKER M, MALLI R, FERTSCHAI I, LEVAK-FRANK S, GRAIER WF: Uncoupling proteins 2 and 3 are fundamental for mitochondrial $\mathrm{Ca}^{2+}$ uniport. Nat Cell Biol 9: 445-452, 2007.

URBÁNKOVÁ E, VOLTCHENKO A, POHL P, JEŽEK P, POHL EE: Transport kinetics of uncoupling proteins: analysis of UCP1 reconstituted in planar lipid bilayers. J Biol Chem 278: 32497-32500, 2003. 
VIDAL-PUIG AJ, GRUJIC D, ZHANG C-Y, HAGEN T, BOSS O, IDO Y, SZCZEPANIK A, WADE J, MOOTHA V, CORTRIGHT R, MUOIO DM, LOWELL BB: Energy metabolism in uncoupling protein-3 gene knockout mice. J Biol Chem 275: 16258-16266, 2000.

WINKLER E, KLINGENBERG M: An improved procedure for reconstitution of the uncoupling protein and in-depth analysis of $\mathrm{H}^{+} / \mathrm{OH}^{-}$transport. Eur J Biochem 207: 135-145, 1992.

WINKLER E, KLINGENBERG M: Effect of fatty acids on $\mathrm{H}^{+}$transport activity of the reconstituted uncoupling protein. J Biol Chem 269: 2508-2515, 1994.

WU Z, ZHANG J, ZHAO B: Superoxide anion regulates the mitochondrial free $\mathrm{Ca}^{2+}$ through uncoupling proteins. Antioxid Redox Signal 11: 1805-1818, 2009.

YANG KS, KANG SW, WOO HA, HWANG SC, CHAE HZ, KIM K, RHEE SG: Inactivation of human peroxiredoxin I during catalysis as the result of the oxidation of the catalytic site cysteine to cysteine sulfinic acid. $J$ Biol Chem 277: 38029-38036, 2002.

YU XX, MAO W, ZHONG A, SCHOW P, BRUSH J, SHERWOOD SW: Characterization of novel UCP5/BMCP1 isoforms and differential regulation of UCP4 and UCP5 expression through dietary or temperature manipulation. FASEB J 14: 1611-1618, 2000.

ZHAO F, WANG Q: The protective effect of peroxiredoxin II on oxidative stress induced apoptosis in pancreatic $\beta$-cells. Cell Biosci 2: 22, 2012.

ZHANG C-Y, BAFFY G, PERRET P, KRAUSS S, PERONI O, GRUJIC D, HAGEN T, VIDAL-PUIG AJ, BOSS O, KIM Y-B, ZHENG XX, WHEELER MB, SHULMAN GI, CHAN CB, LOWELL BB: Uncoupling protein-2 negatively regulates insulin secretion and is a major link between obesity $\beta$-cell dysfunction and type 2 diabetes. Cell 105: 745-755, 2001.

ZHANG CY, PARTON LE, YE CP, KRAUSS S, SHEN R, LIN CT, PORCO JA JR, LOWELL BB: Genipin inhibits UCP2-mediated proton leak and acutely reverses obesity- and high glucose-induced beta cell dysfunction in isolated pancreatic islets. Cell Metab 3: 421-427, 2006.

ŽÁČKOVÁ M, ŠKOBISOVÁ, E, URBÁNKOVÁ E, JEŽEK P: Activating $\omega-6$ polyunsaturated fatty acids and inhibitory purine nucleotides are high affinity ligands for novel mitochondrial uncoupling proteins UCP2 and UCP3. J Biol Chem 278: 20761-20769, 2003. 